Acta Agroph., 2018, 25(4), 385-396

doi: $10.31545 /$ aagr/99211

\title{
IMPACT OF GROWTH BIOSTIMULATORS AND HERBICIDE ON EDIBLE POTATO YIELD
}

\author{
Alicja Joanna Baranowska \\ Department of Agriculture, Institute of Agriculture \\ Pope John II State School of Higher Education in Biala Podlaska \\ ul. Sidorska 95/97, 21-500 Biała Podlaska, Poland \\ e-mail: alabar@tlen.pl
}

\begin{abstract}
The aim of the study was to define the influence of cultivation methods involving the application of growth biostimulators and herbicide on the total yield of edible potato. The field research was conducted in 2015-2017 in the area of eastern Poland, in Lublin Voivodeship. The experiments were performed in three replicates using the randomised split-block method. The examined factors included: factor I - three early cultivars of edible potato (Owacja, Bellarosa, Vineta), factor II - cultivation methods involving the application of growth biostimulators and herbicide: GreenOK-Universal Pro and Asahi SL as well as their combination with the Avatar 293 ZC herbicide. The highest total yield of tubers was obtained from treatment 4 , where prior to sprouting mechanical tillage was used, and after the final shaping of ridges and just before sprouting the Avatar 293 ZC herbicide was applied at a dose of $1.5 \mathrm{dm}^{3} \mathrm{ha}^{-1}$, and then after sprouting the GreenOK Universal-PRO was applied three times at doses: $0.10 \mathrm{dm}^{3} \mathrm{ha}^{-1}$ - full moon-end of seeding $+0.15 \mathrm{dm}^{3} \mathrm{ha}^{-1}$ - covering inter-rows $+0.15 \mathrm{dm}^{3} \mathrm{ha}^{-1}$ - formation of flower buds (an average of $41.8 \mathrm{tha}^{-1}$ ), and from treatment 5 , in which mechanical tillage was used prior to seeding, and after the ultimate formation of furrows before seeding of potato plants, Avatar herbicide 293 was applied in a dose of $1.5 \mathrm{dm}^{3} \mathrm{ha}^{-1}$ (total yield amounted to, on average, $40.6 \mathrm{t} \mathrm{ha}^{-1}$ ). Potato cultivars cultivated in the experiment and meteorological conditions during the conducted tests also had a significant impact on the size of the total yield. Cultivar Owacja produced the highest yields (an average of $41.4 \mathrm{t} \mathrm{ha}^{-1}$ ). The largest total yield was collected in 2016 (an average of $42.8 \mathrm{tha}^{-1}$ ). A significant influence of the experimental factors on the structure of large tuber yields was also found.
\end{abstract}

Keywords: potato, total yield, biostimulators, herbicide 


\section{INTRODUCTION}

One of the most important quality characteristics, from the perspective of the market and processing of potato tubers, is the amount and quality of the total yield and its structure (the size of tubers). With regard to the increasing quality requirements, technology of potato cultivation requires extensive knowledge and diligence (Đalovic et al. 2008, Sawicka 2009).

It should also be emphasised that the achievement of high quality of yields with pro-health values and protection of natural environment and human health are the main objectives which are set by food producers. Therefore, in the $21^{\text {st }}$ century, farming limitation of the use of mineral fertilisers and chemical agents for plant protection, such as herbicides, insecticides and fungicides, is strived for and more and more often preparations of natural origin are used (Filipczak et al. 2016). In numerous countries, the tendency to restore biological diversity in agrocenosis is observed (Japan, Western Europe, Brazil, and USA). Also in Poland, biostimulators, which are preparations friendly for the environment and consumer health, are becoming increasingly popular, due to the fact that they contain biologically active natural compounds. Such preparations include, inter alia, growth regulators, plant growth and nutrition stimulators, plant resistance stimulators and soil improvers (Zydlik and Zydlik 2013, Kołodziejczyk 2014, Filipczak et al. 2016, Pszczółkowski and Sawicka 2018). They may be applied in conventional, integrated and ecological agriculture (Pieńkowska 2017).

In agricultural plant production, the term "biostimulator" is used with regard to preparations which exert a positive impact on the growth of cultivated plants, but are not considered as fertilisers. It should be noted that currently in Poland there is no legally applicable definition of biostimulators. However, according to the definition proposed in the report for the European Commission, plant biostimulator constitutes material which contains substance/s or microorganisms and is destined for use on a plant, seeds or root area in order to stimulate natural processes increasing the effectiveness of nutrients use, tolerance for abiotic stress and/or the quality of yield, the action of which is not dependent on the contents of nutrients (Taron et al. 2014, Matyjaszczyk 2015).

Scientific elaborations indicate that the use of biostimulators has a positive influence on the growth and general condition of plants and on the size and quality of collected yields. In Poland, the positive influence of biostimulators on plant growth and development was documented by numerous authors (Żurawicz et al. 2004, Marjańska-Cichoń and Sapieha-Waszkiewicz 2010, Zarzecka and Gugała 2012, Gugała et al. 2018). However, the mechanism of action of these preparations has not been fully discovered yet. 
Growing demand for preparations of biological origin and the need of natural environment protection make searching for new, safe remedies and knowledge about their influence on cultivated plant yields become a necessity (Panasiewicz et al. 2007).

So far, the few available empirical results of research on the influence of biostimulators on total yield and yield structure of edible potato encourage conducting further research. Therefore, the aim of the experiment was to define the influence of cultivation methods with the use of growth biostimulators and herbicide on the total yield and large tubers yield of three cultivars of edible potato.

\section{MATERIALS AND METHODS}

\section{Experiment and plant material}

The field experiment was conducted in the years 2015-2017 in the region of eastern Poland, in the Biała Podlaska Commune $\left(52^{\circ} 02^{\prime} \mathrm{N}\right.$; $\left.23^{\circ} 07^{\prime} \mathrm{E}\right)$ in the Lublin Voivodeship, on acidic light soil. The experiment was carried out with the use of randomised split-block method in the split-plot system. The influence of two factors was tested: Factor I - three early edible potato cultivars: Bellarosa, Owacja, Vineta, and Factor II - cultivation methods involving the application of growth biostimulators and herbicide:

1. Standard treatment - mechanical tillage (without biostimulators and herbicide).

2. Prior to sprouting of potato plants mechanical tillage, and after sprouting GreenOK Universal-PRO bioactivator, three times to leaves: at a dose of $0.10 \mathrm{dm}^{3} \mathrm{ha}^{-1}$ - peak-end of sprouting (phase BBCH 13-19) $+0.15 \mathrm{dm}^{3} \mathrm{ha}^{-1}$ - covering of interrows (phase BBCH 31-35) $+0.15 \mathrm{dm}^{3} \mathrm{ha}^{-1}$ - flower bud break (phase BBCH 51-55).

3. Prior to sprouting of potato plants - mechanical treatment, and after sprouting, Asahi SL bioactivator, three times to leaves at a dose of $0.50 \mathrm{dm}^{3} \mathrm{ha}^{-1}$ - peak-end of sprouting (phase BBCH 13-19) $+0.50 \mathrm{dm}^{3} \mathrm{ha}^{-1}$ - covering of interrows (phase BBCH 31-35) $+0.50 \mathrm{dm}^{3} \mathrm{ha}^{-1}$ - flower bud break (phase BBCH 51-55).

4. Prior to sprouting mechanical tillage, and after the final shaping of ridges and just before sprouting Avatar $293 \mathrm{ZC}$ herbicide at a dose of $1.5 \mathrm{dm}^{3} \mathrm{ha}^{-1}$ (phase BBCH 00-05). After sprouting, three applications of GreenOK Universal-PRO bioactivator at a dose of $0.10 \mathrm{dm}^{3} \mathrm{ha}^{-1}$ - peak-end of sprouting (phase BBCH 13-19) $+0.15 \mathrm{dm}^{3} \mathrm{ha}^{-1}-$ covering of interrows (phase BBCH 31-35) $+0.15 \mathrm{dm}^{3} \mathrm{ha}^{-1}-$ flower bud break (phase BBCH 51-55).

5. Prior to sprouting mechanical tillage, and after the final shaping of ridges before sprouting of potato plants Avatar $293 \mathrm{ZC}$ herbicide at a dose of $1.5 \mathrm{dm}^{3} \mathrm{ha}^{-1}$ (phase $\mathrm{BBCH} 00-05$ ).

The characteristics of the potato varieties and preparations used in the experiment are presented in Table 1 and Table 2. 
Table 1. Characteristics of potato cultivars grown in the experiment

\begin{tabular}{lcclc}
\hline Variety & $\begin{array}{c}\text { Year of } \\
\text { inscription to } \\
\text { variety register }\end{array}$ & Breeder of variety & Delegate retaining variety & $\begin{array}{c}\text { Yield } \\
\text { tha }^{-1}\end{array}$ \\
\hline Bellarosa & 2006 & $\begin{array}{c}\text { Europlant, Pflz. } \\
\text { GmbH, Germany }\end{array}$ & $\begin{array}{l}\text { Europlant. Handel Ziemniakami, sp. z o.o.; } \\
\text { Laski Koszalińskie 3A, 76-039 Biesiekierz } \\
\text { Owacja }\end{array}$ Pomorsko-Mazurska Hodowla Ziemniaka, \\
Vineta & 1999 & $\begin{array}{c}\text { PMHZ Strzekęcino } \\
\text { sp. z o.o., Strzekęcino, 76-024 Świeszyno } \\
\text { EmbH, Germany }\end{array}$ & 41.4 \\
\hline
\end{tabular}

Source: Plant Breeding and Acclimatisation Institute - National Research Institute 2017

Table 2. Characteristics of preparations used in the experiment

\begin{tabular}{|c|c|c|c|}
\hline $\begin{array}{l}\text { Name of } \\
\text { preparation }\end{array}$ & $\begin{array}{c}\text { Holder of } \\
\text { authorisation }\end{array}$ & Content of active substances & Action of preparation \\
\hline $\begin{array}{l}\text { GreenOK } \\
\text { Universal-PRO } \\
\text { - natural } \\
\text { fertiliser with } \\
\text { biostimmulating } \\
\text { effect }\end{array}$ & $\begin{array}{l}\text { Latvian Institute } \\
\text { of humic } \\
\text { substances } \\
\text { Brivibas Street } \\
\text { 144, Riga, } \\
\text { Latvia, LV-1012 }\end{array}$ & $\begin{array}{c}\text { humus substances } \geq 20 \mathrm{~g} \mathrm{dm}^{3} \\
\text { (NPK } 0.13-0.09-0.7) \\
\text { dry matter } 22 \mathrm{~g} \mathrm{dm}^{3} \\
\text { humidity } 96 \% \text {, organic substances } \\
3 \% \text {, pH 7-9 }\end{array}$ & $\begin{array}{c}\text { increase of bioavailability of } \\
\text { nutritional compounds, } \\
\text { reduction of negative impact of } \\
\text { bad environmental conditions, } \\
\text { stimulation and growth of } \\
\text { weakened parts of plants, } \\
\text { extension of the flowering } \\
\text { period and increase of the } \\
\text { number of flowers }\end{array}$ \\
\hline $\begin{array}{l}\text { Asahi SL } \\
\text { - growth } \\
\text { regulator }\end{array}$ & $\begin{array}{l}\text { Asahi Chemical } \\
\text { Europe s.r.o., } \\
\text { Lužná 591/4- } \\
\text { Vokovice, } 160 \\
\text { 00 Praha 6, The } \\
\text { Czech Republic }\end{array}$ & $\begin{array}{c}\text { sodium para-nitrophenolate } \\
\text { (substance of nitrophenoles group) } \\
-3 \mathrm{~g} \mathrm{dm}^{3}(0.3 \%) \\
\text { sodium ortho-nitrophenolate } \\
\text { (substance of nitrophenolates group) } \\
\quad-2 \mathrm{~g} \mathrm{dm}^{3}(0.2 \%) \\
\text { sodium } 5 \text {-nitroguaiacolate- } \\
\text { (substance of nitrophenolates group } \\
\text { derivatives) }-1 \mathrm{~g} \mathrm{dm}^{3}(0.1 \%)\end{array}$ & $\begin{array}{l}\text { causes higher yielding and } \\
\text { amelioration of yields quality. } \\
\text { The use of this preparation is } \\
\text { advised in stress-generating } \\
\text { conditions, unfavourable for the } \\
\text { growth of plants }\end{array}$ \\
\hline $\begin{array}{l}\text { Avatar } 293 \text { ZC } \\
\text { - herbicide }\end{array}$ & $\begin{array}{c}\text { FMC Chemical } \\
\text { sprl, Boulevard } \\
\text { de la Plaine } 9 / 3 \text {, } \\
\text { B-1050 } \\
\text { Brussels, The } \\
\text { Kingdom } \\
\text { of Belgium }\end{array}$ & $\begin{array}{l}\text { clomazone (substance of } \\
\text { isoxalodine group) }-60 \mathrm{~g} \mathrm{dm}^{3} \\
(5.13 \%) \text {. } \\
\text { metribuzin (substance of } \\
\text { triazinones group) }-233 \mathrm{~g} \mathrm{dm}^{3} \\
(20.64 \%) .\end{array}$ & $\begin{array}{l}\text { clomazone is absorbed by roots } \\
\text { and under-cotyledon part of } \\
\text { plants, it inhibits the synthesis } \\
\text { of pigments (chlorophyll and } \\
\text { carotenoids) in plants. } \\
\text { Metribuzin is absorbed by the } \\
\text { roots and leaves, inhibiting } \\
\text { photosynthesis process }\end{array}$ \\
\hline
\end{tabular}

Source: Information disclosed by agents' manufacturers

Each year in autumn, before the experiments, natural manure fertilisation was applied at a dose of $25 \mathrm{t} \mathrm{ha}^{-1}$, as well as mineral fertilisation with phosphorus $44.0 \mathrm{~kg} \mathrm{Pha}^{-1}$ (triple superphosphate $46 \%$ ) and potassium $124.5 \mathrm{~kg} \mathrm{~K} \mathrm{ha}^{-1}$ (potassium 
salt $60 \%$ ), and in spring - nitrogen fertilisation (ammonium nitrate $34 \%$ ) at a dose of $100 \mathrm{~kg} \mathrm{~N}$ per 1 ha. Potato tubers were planted in the second decade of April (in 2015 and 2016) and in the third decade of April (in 2017). Protection treatments against diseases and pests were used in accordance with the plant protection recommendations. Harvest was performed in the phase of full technological maturity of tubers.

Sample tubers from 10 potato plants (excluding edge plants) were taken randomly from every treatment of the experiment during harvest. In those samples, yield structure was defined by extracting fractions according to transverse diameter: up to 35, 36-50, 51-60 and above $60 \mathrm{~mm}$ (Regulation 2003). The total potato yield was calculated on the basis of the tubers' mass collected from the surface of each minor plot, adding the mass of previously collected samples, and in the yield of large tubers, fractions of 51-60 $\mathrm{mm}$ and over $60 \mathrm{~mm}$ diameter were taken into account.

\section{Statistical analysis}

The obtained results of research regarding total yields of tubers were analysed statistically by means of the analysis of variance. Significance of variability sources was tested with the Fischler-Snedecor F test, and the assessment of significance of variance at the significance level $p=0.05$ between the compared averages using Tukey's range test (Trętowski and Wójcik 1988).

\section{Weather conditions}

Meteorological conditions in potato growing season are presented in Table 3. The data come from the Meteorological Station of the Research Centre for Cultivar Testing (COBORU) in Stupia Wielka and they were compiled for the Cultivar Assessment Experimental Station in Cicibór Duży, situated near Biała Podlaska.

Table 3. Meteorological conditions during the potato vegetation periods in 2015-2017

\begin{tabular}{|c|c|c|c|c|c|c|c|c|}
\hline \multirow{3}{*}{ Months } & \multicolumn{4}{|c|}{ Air temperatures $\left({ }^{\circ} \mathrm{C}\right)$} & \multicolumn{4}{|c|}{ Rainfall (mm) } \\
\hline & \multicolumn{2}{|l|}{ multi-year mean } & \multicolumn{2}{|l|}{ Mean } & \multirow{2}{*}{$\begin{array}{c}\text { multi-year mean } \\
1990-2010\end{array}$} & \multicolumn{3}{|c|}{ sum } \\
\hline & $1990-2010$ & 2015 & 2016 & 2017 & & 2015 & 2016 & 2017 \\
\hline$\overline{\mathrm{IV}}$ & 8.3 & 8.3 & 9.7 & 7.7 & 38 & 36 & 35 & 62 \\
\hline $\mathrm{V}$ & 13.9 & 12.8 & 15.0 & 13.8 & 61 & 91 & 22 & 40 \\
\hline VI & 17.0 & 16.7 & 18.4 & 18.0 & 60 & 30 & 84 & 106 \\
\hline VII & 19.4 & 19.6 & 19.8 & 18.5 & 77 & 49 & 121 & 71 \\
\hline VIII & 18.3 & 21.6 & 18.7 & 19.9 & 68 & 7 & 28 & 41 \\
\hline IX & 12.7 & 15.1 & 15.2 & 14.7 & 57 & 75 & 12 & 105 \\
\hline IV-IX mean & 14.9 & 15.7 & 16.1 & 15.4 & 361 & 288 & 302 & 425 \\
\hline \multicolumn{9}{|c|}{ * Sielianinov's hydrothermic coefficients } \\
\hline Months/Year & IV & V & VI & VII & VIII & IX & \multicolumn{2}{|c|}{ Mean IV-IX } \\
\hline 2015 & 1.43 & 2.28 & 0.59 & 0.80 & 0.11 & 1.66 & \multicolumn{2}{|c|}{0.99} \\
\hline 2016 & 1.19 & 0.47 & 1.53 & 1.97 & 0.48 & 0.26 & \multicolumn{2}{|c|}{1.00} \\
\hline 2017 & 2.68 & 0.93 & 1.97 & 1.24 & 0.66 & 2.37 & \multicolumn{2}{|c|}{1.50} \\
\hline
\end{tabular}

*Coefficient value (Bac at al. 1998): < 0.5 - strong drought; 0.51-0.69 - semi drought; 0.70-0.99 poor drought; $\geq 1$ - fault drought 
Meteorological conditions were diverse during the study period (Tab. 3). The highest precipitation sum was recorded in the growing season of 2017-425 mm, in which the average air temperature was $15.4^{\circ} \mathrm{C}$; it was the coldest year in comparison with the other years covered by the research. In addition, April was a cold month - average air temperature amounted to $7.7^{\circ} \mathrm{C}$, and July brought a wave of frost with snow and sleet. The lowest precipitation sum $-288 \mathrm{~mm}$ - was recorded in 2015 with an average air temperature of $15.7^{\circ} \mathrm{C}$. In that season, a precipitation shortage occurred from June to August (i.e. during flowering, tuber formation and yield accumulation), while August was extremely dry with precipitation sum of $7 \mathrm{~mm}$ and high atmospheric air temperatures. The growing season of 2016 was characterised by precipitation sum at the level of $361 \mathrm{~mm}$ and air temperature amounting to $16.1^{\circ} \mathrm{C}$, higher by $1.2^{\circ} \mathrm{C}$ than the average air temperature from the multi-year period (1990-2010); it was a favourable season for plant growth and yield accumulation. Whilst, in the months of July and August the average ambient air temperatures were similar to the temperatures of the multiannual period. It was a favourable season for the potato crop.

\section{RESULTS AND DISCUSSION}

As a result of the research carried out it was proved that both the cultivation methods applied, potato cultivars cultivated in the experiment, as well as meteorological conditions in the particular research years had a significant impact on the size of the total yield of potato tubers (Tab. 4).

Table 4. Total yield of potato tubers ( $\mathrm{t} \mathrm{ha}^{-1)}$ (average for varieties and years 2015-2017)

\begin{tabular}{|c|c|c|c|c|c|c|c|}
\hline \multirow{2}{*}{$\begin{array}{c}\text { Weed control } \\
\text { methods }\end{array}$} & \multicolumn{3}{|c|}{ Cultivar } & \multicolumn{3}{|c|}{ Years } & \multirow{2}{*}{ Mean } \\
\hline & Bellarosa & Owacja & Vineta & 2015 & 2016 & 2017 & \\
\hline $1 *$ & 30.1 & 35.0 & 32.3 & 28.3 & 36.6 & 32.5 & 32.5 \\
\hline 2 & 34.3 & 40.9 & 37.7 & 33.0 & 42.3 & 37.6 & 37.6 \\
\hline 3 & 35.5 & 42.2 & 39.0 & 35.1 & 43.2 & 38.4 & 38.9 \\
\hline 4 & 38.8 & 45.0 & 41.5 & 38.1 & 46.6 & 40.6 & 41.8 \\
\hline 5 & 37.7 & 43.9 & 40.2 & 36.5 & 45.5 & 39.7 & 40.6 \\
\hline Mean & 35.3 & 41.4 & 38.1 & 34.2 & 42.8 & 37.8 & 38.3 \\
\hline \multicolumn{8}{|l|}{$\operatorname{LSD}(0.05)$ for: } \\
\hline \multicolumn{7}{|l|}{ Years } & 0.687 \\
\hline \multicolumn{7}{|l|}{ Cultivar } & 0.687 \\
\hline \multicolumn{7}{|c|}{ Weed control methods } & 0.843 \\
\hline \multicolumn{7}{|c|}{ Years $\times$ cultivar } & n.s. \\
\hline \multicolumn{7}{|c|}{ Years $\times$ weed control methods } & n.s. \\
\hline \multicolumn{7}{|c|}{ Cultivar $\times$ weed control methods } & n.s. \\
\hline
\end{tabular}

*markings as per research methodology 
The cultivation methods applied in the experiment with the use of growth biostimulators and herbicide caused a significant increase in the yield of potato tubers (object 2.-5.) in comparison to the application of mechanical tillage alone (treatment 1) (Tab.4). The highest total yield of tubers was obtained from treatment 4 , (where mechanical tillage was applied prior to sprouting, followed by the application of Avatar $293 \mathrm{ZC}$ herbicide at a dose of $1.5 \mathrm{dm}^{3} \mathrm{ha}^{-1}$, and GreenOK Universal-PRO bioactivator at a dose of $0.10 \mathrm{dm}^{3} \mathrm{ha}^{-1}+0.15 \mathrm{dm}^{3} \mathrm{ha}^{-1}+0.15 \mathrm{dm}^{3} \mathrm{ha}^{-1}$ three times after sprouting) (total yield amounted to, on average, $41.8 \mathrm{t} \mathrm{ha}^{-1}$ ) and from treatment 5. where mechanical tillage was applied, followed by Avatar $293 \mathrm{ZC}$ herbicide at a dose of $1.5 \mathrm{dm}^{3} \mathrm{ha}^{-1}$ (total yield amounted to, on average, $40.6 \mathrm{t} \mathrm{ha}^{-1}$ ). These results are consistent with the research of Gugała et al. (2017) who obtained the highest total rise in yield of potato tubers applying the Sencor $70 \mathrm{WG}$ herbicide just before sprouting and then the Asahi SL biostimulator twice. A beneficial effect of the application of biostimulators on yielding of cultivated plants was also recorded by Matysiak et al. (2011), Kalinowski and Wadas (2017). Mikos-Bielak and Czeczko (2002), assessing the effective application of Atonik biostimulator in the cultivation of medium late potato Ania, demonstrated that single application of $0.1 \%$ solution of this preparation on leaves before flowering increased the total yield by around $14 \%$. Trawczyński (2014), after the application of amino acid biostimulator Tecamin, obtained an increase in yield by an average of $13.8 \%$, while Frackowiak-Pawlak (2011) proved a 30\% increase in the yield of edible potato tubers after the use of UGmax.

Miklos-Bielak (2005) found, in her study, that from the practical point of view, in potato production the most important may be those growth regulators that, among other things, increase the yield of potato and the number of tubers with specified calibration. According to the author, increasing yield of potato tubers can be obtained through an increase in the number of stems, for example, by accelerating the germination and sprouting, increase of the assimilation surface of the entire plant, stimulating the development of the stolon and accelerating the binding of tubers.

On the other hand, Maciejewski et al. (2007), based on a two-year study conducted in two locations differing in terms of habitats, found that the biostimulators Asahi SL and Atomik SL applied in the experiment did not have any major impact on the yield of potato, its structure and quality characteristics. Also Condor et al. (2006) expressed a sceptical view on the application of biostimulators in agricultural crops, stressing the need for further scientific research on the use of such preparations.

As a result of this study, it was found that the size of the total yield of tubers is significantly impacted also by the varieties of potato (Table 4). From amongst the cultivated varieties, Owacja had the highest yields (an average of $41.4 \mathrm{t} \mathrm{ha}^{-1}$ ), significantly higher than the yields of the varieties Bellarosa (an average of $35.3 \mathrm{t} \mathrm{ha}^{-1}$ ) and Vineta (an average of $38.1 \mathrm{t} \mathrm{ha}^{-1}$ ). The results of our research find support 
in the reports of Urbanowicz (2010), Zarzecka et al. (2013), Pszczółkowski and Sawicka (2018), Gugała et al. (2018), who showed that tuber yield was dependent on the genetic characteristics of the cultivated varieties of potato. According to Rymuza et al. (2017) genotypes which yield high and stable in various soil-climate conditions will be sought in the farming practice.

The conducted research showed that the total yield of potato tubers in fact depended on the course of the weather conditions in the years of the study (Table 3 and 4). In the study, the growing season of 2016 proved to be the most beneficial for the potato crop (the average total yield was $42.8 \mathrm{t} \mathrm{ha}^{-1}$ ); in that season the weather conditions were the most favourable for the growth and development of potato plants in comparison to the remaining years of research. By contrast, the smallest total tuber yield was obtained in the year 2015 (average of $34.2 \mathrm{tha}^{-1}$ ), in which during flowering, tuber formation and accumulation of yields there was a shortage of precipitation (June-August).

According to Skowera et al. (2016), Kundzewicz and Matczak (2010), adverse weather conditions, which can be considered as dry and moist, contribute to a substantial reduction of the yields. However, the cultivation of potato varieties tolerant to periodic shortages of rainfall can partially compensate the losses of yield caused by this phenomenon (Puła and Skowera 2004).

By analysing the weight percentage share of large tubers yield in fractions of 51-60 and above $60 \mathrm{~mm}$ in the total yield of potato tubers, it was found that this share was larger in all the treatments of the experiment after the application of growth biostimulants and herbicides in comparison to the control treatment (Table 5 and 6).

Table 5. Share of the yield of large tubers (fractions of 51-60 mm) in total yield of potato tubers (\%) (average for varieties and years 2015-2017)

\begin{tabular}{lccccccc}
\hline \multirow{2}{*}{$\begin{array}{c}\text { Weed control } \\
\text { methods }\end{array}$} & \multicolumn{5}{c}{ Cultivar } & Years & \multirow{2}{*}{ Mean } \\
\cline { 2 - 7 } & Bellarosa & Owacja & Vineta & 2015 & 2016 & 2017 & \\
\hline $1^{*}$ & 27.66 & 35.33 & 32.66 & 29.33 & 35.33 & 31.00 & 31.88 \\
3 & 32.00 & 40.33 & 35.00 & 30.33 & 38.66 & 38.33 & 35.77 \\
4 & 35.33 & 43.66 & 37.66 & 36.66 & 40.00 & 40.00 & 38.88 \\
5 & 36.66 & 52.00 & 39.66 & 39.00 & 44.66 & 44.66 & 42.77 \\
Mean & 32.66 & 45.33 & 37.00 & 33.33 & 41.00 & 40.66 & 38.33 \\
\hline
\end{tabular}

*markings as per research methodology

The largest percentage of large tubers (in fractions of 51-60 and $>60 \mathrm{~mm}$ ) in total yield was found in treatment 4. and it amounted to, on average: for fractions of 51-60 - 42.77\% and for factions $>60 \mathrm{~mm}-38.77 \%$ (Table 5 and 6). These results are consistent with the research of Trawczyński (2014) who, after the application of foliar biostimulator fertilisers, obtained a greater share of the commercial 
yield in the total yield by $3.9 \%$ compared with the treatment without foliar feeding. Matysiak and Adamczewski (2010) proved that feeding with foliar biostimulators increases the share of large tubers (with diameter of more than $60 \mathrm{~mm}$ ) in the yield by up to $45 \%$ in comparison to the control treatment. Kowalska (2016), after the application of biostimulator preparations, observed an increase of potato yield and the share of commercial tubers in the yield.

Table 6. Share of the yield of large tubers (fractions $>60 \mathrm{~mm}$ ) in total yield of potato tubers (\%) (average for varieties and years 2015-2017)

\begin{tabular}{lccccccc}
\hline \multirow{2}{*}{$\begin{array}{c}\text { Weed control } \\
\text { methods }\end{array}$} & \multicolumn{5}{c}{ Cultivar } & \multicolumn{3}{c}{ Years } & \multirow{2}{*}{ Mean } \\
\cline { 2 - 7 } $1 *$ & Bellarosa & Owacja & Vineta & 2015 & 2016 & 2017 & 24.44 \\
2 & 46.66 & 15.66 & 11.00 & 20.33 & 31.00 & 22.00 & 26.88 \\
3 & 47.00 & 18.00 & 15.66 & 21.33 & 33.66 & 25.66 & 32.88 \\
4 & 56.00 & 24.33 & 18.33 & 31.66 & 34.66 & 32.33 & 38.77 \\
5 & 56.33 & 28.66 & 31.33 & 36.00 & 41.33 & 39.00 & 29.88 \\
Mean & 53.33 & 20.33 & 16.00 & 26.33 & 31.00 & 32.33 & 30.57 \\
\hline
\end{tabular}

*markings as per research methodology

In the course of our studies, the structure of yield was modified by the genetic characteristics of varieties. The largest share of large tubers (in the fractions $>60 \mathrm{~mm}$ ) was characteristic of the Bellarosa variety (average of 51.86\%), and the smallest - Vineta (average of 18.46\%) (Table 6). Whereas, the largest percentage of large tuber yield in the fraction of 51-60 $\mathrm{mm}$ was reported in the Owacja variety (Table 5). The structure of potato yield was also impacted by weather conditions in the respective years of research. The most favourable for the formation of large tuber yield was the growing season of the year 2016 (Table 5 and 6). In that season, the share of mass of tubers with a diameter of $51-60 \mathrm{~mm}$ in the yield averaged at $39.93 \%$ (Table 5), and with diameters $>60 \mathrm{~mm}-34.33 \%$. In the study by Kołodziejczyk (2013), the fraction of large tubers constituted the largest yield mass in optimal or quite wet years in pluvio-thermal terms, significantly less than in quite dry years, and the smallest in extremely humid years. According to Schenck and Müller (2009), the use of biostimulating preparations in favourable growing seasons has a positive effect on the yielding of plants. Kocon and Jadczyszyn (2015) demonstrated that suitable soil humidity and air temperature resulted in the development of soil microorganisms and an increase of the effectiveness of biostimulating preparations. 


\section{CONCLUSIONS}

1. The total yield of edible potato tubers depended significantly on cultivation methods. Growth biostimulators and herbicide application in the experiment had a positive impact on obtaining higher yields of tubers in comparison to the control treatment with mechanical tillage alone.

2. The most effective way to treat potato cultivations in terms of total yield size was the use of mechanical tillage for rising plants, and just before sprouting - the use of herbicide Avatar 293 ZC, whilst after sprouting - triple application of the bioactivator GreenOK Universal-PRO (object 4.) and until sprouting, the use of mechanical tillage and just before sprouting, herbicide Avatar 293 ZC (treatment 5.).

3. Genetic characteristics of varieties and weather conditions in the years of research had a significant effect on the size of total yield. The variety with the highest yielding size was Owacja. The largest potato yields were obtained in favourable weather conditions in 2016.

4. The experimental factors modified the structure of the potato yield. A greater share of large potato tubers yield in the total yield was obtained in all experimental treatments after the application of growth biostimulators and herbicide in comparison to the control treatment.

\section{REFERENCES}

Bac S., Koźmiński Cz., Rojek M., 1998. Agrometeorology (in Polish). PWN, Warsaw.

Condor A. F., Perez P. G., Lokare Ch., 2006. Effective Microorganisms: Myth or reality. Revista Peruana de Biologia, 14(2), 315-320.

Đalovic I., Miloševič D., Macák M., Týr Š., 2008. Impact of weed control on potato infestation and yield. RJAS, 40(1), 385-388.

Filipczak J., Żurawicz E., Sas Paszt L., 2016. Impact of Selected Biostimulators on Growth and Yielding of „Elkat” Strawberry (in Polish). Zesz. Nauk. Inst. Ogrod., 24, 43-58.

Frąckowiak-Pawlak K., 2011. The Results of Multi-year Experiments with UGmax (in Polish). Poradnik Gospodarski, 2, 11.

Gugała M., Zarzecka K., Sikorska A., Mystkowska I., Dołęga H., 2017. Impact of Herbicides and Growth Biostimulators on Limitation of Infestation and on Yielding of Edible Potato (in Polish). Fragm. Agron., 34(4), 59-66.

Gugała M., Zarzecka K., Sikorska A., Dołęga H., 2018. Occurrence of defects of potato tubers in conditions of application of herbicides and biostimulants. Acta Sci. Pol. Agricultura, 17(1), 13-22.

Kalinowski K., Wadas W., 2017. Effect of Tytanit ${ }^{\circledR}$ on the yield and yield components of very early-maturing potato cultivars. J. Central Europ. Agricul., 18(2), 441-459, doi:10.5513/JCEA01/ 18.2.1917

Kocoń A., Jadczyszyn T., 2015. The Impact of Microbiological Preparations, Methods of Their Use and the Doses of Nitrogen Fertilization on the Content of Assimilated Phosphorus in Soil and Other Selected Indicators of Chemical Soil Fertility (in Polish). Polish Journal of Agronomy, 21, 11-18.

Kołodziejczyk M., 2013. Phenotypic Variability in Yielding, Chemical Composition and Quality Attributes of Selected Medium Late Tubers (in Polish). Acta Agroph., 20(3), 411-422. 
Kołodziejczyk M., 2014. Effectiveness of nitrogen fertilization and application of microbial preparations in potato cultivation. Turk. J. Agric. For., 38, 299-310, doi:10.3906/tar-1305-105

Kowalska J., 2016. Effect of fertilization and microbiological bio-stimulators on healthiness and yield of organic potato (in Polish). Progress in Plant Protection/Postępy w Ochronie Roślin, 56(2), 230-235.

Krzysztofik B., 2009. The Effect of Tillage on the Degree of Uniformity of the Tuber Size and Starch Yield (in Polish). Acta Agroph., 14(2), 355-365.

Kundzewicz Z.W., Matczak P., 2010. Threats of Natural Extreme Events (in Polish). Nauka, 4, 77-86.

Maciejewski T., Szukała J., Jarosz A., 2007. Influence of biostimulators Asahi SL and Atonik SL on qualitative features of tubers of potatoes. J. Res. Appl. Agric. Eng., 52(3), 109-112.

Marjańska-Cichoń B., Sapieha-Waszkiewicz A., 2010. The Effect of preparations Asahi SL and Tytanit on the Growth and Yielding of Strawberry Variety Salut (in Polish). Progress in Plant Protection/Postępy w Ochronie Roślin, 50(1), 383-388.

Matyjaszczyk E., 2015. Introduction of Biostimulators for Trade in Poland. The Current Situation and Legal Considerations (in Polish). Przemysł Chemiczny, 94(10), 1841-1844.

Matysiak K., Adamczewski K., 2010. The Effect of Plant Growth and Development Regulators Moddus 250 EC, Kelpak SL, Algaminoplant, Humiplant and Yeald Plus on Yielding and size of Potato Tubers (in Polish). Ziemniak Polski, 1, 28-33.

Matysiak K., Adamczewski K., Kaczmarek S., 2011. The Influence of Biostimulator Asahi SL on Yielding and Selected Quantitative and Qualitative Features of Selected Agricultural Plants Cultivated in Wielkopolska (in Polish). Progress in Plant Protection, 51 (4), 1849-1857.

Mikos-Bielak M., 2005. Exogenous growth regulators in potato cultivation. Annales UMCS, Sec. E, 60, 281-292.

Mikos-Bielak M., Czeczko R., 2002. The Analysis of the Applicability of Atonik-Asahi Growth Stimulator in Cultivation of Potato (in Polish). Zesz. Probl. Post. Nauk Rol., 489, 157-164.

Panasiewicz K., Koziara W., Sulewska H., Skrzypczak W., 2007. The Influence of biological and chemical seed primers on Vigour Parameters of Cereal Grains (in Polish). Progress in Plant Protection/Postępy w Ochronie Roślin, 47(2), 235-239.

Pieńkowska M., 2017. Potential of natural plant extracts for health and vigour improvement of seed material of agricultural crops. Problems of Small Agricultural Holdings, 3, 43-59.

Plant Breeding and Acclimatization Institute - National Research Institute, 2017. Characteristics of the Polish National Register of Cultivars (in Polish). Issue XX. Jadwisin. IHAR.

Pszczółkowski P., Sawicka B., 2018. The effect of application of biopreparations and fungicides on the yield and selected parameters of seed value of seed potatoes. Acta Agroph., 25(2), 239-255, doi:10.31545/aagr/93104

Puła J., Skowera B. (2004). Variability of the Quality Characteristics of Potato Tubers of Mila Variety Cultivated in Light Soil, depending on Weather Conditions (in Polish). Acta Agroph., 3(2), 359-366.

Regulation of the Minister of Agriculture and Rural Development on the detailed requirements in the scope of Trade Quality of Potatoes (in Polish). 2003. (Dz. U. nr 194 poz. 1900 z 2003 roku).

Rymuza K., Radzka E., Lenartowicz T., 2017. Analysis of genotype-environment interaction for the yield of medium early potato cultivars. Biul. IHAR, 281, 59-68.

Schenck M., Müller T., 2009. Impact of effective microorganisms and other biofertilizers on soil microbial characteristics, organic-matter decomposition and plant growth. J. Plant Nutr. Soil Sci., 172, 704-712, doi:10.1002/jpln.200800021

Skowera B., Kopcińska J., Ziernicka-Wojtaszek A., Wojkowski J., 2016. Shortages and Surpluses of Rainfalls During the Growing Season of late potato in Opole Voivodeship (1981-2010) (in Polish). Acta. Sci. Pol., Formatio Circumiectus, 15(3), 137-149, doi:10.15576/ASP.FC/2016.15.3.137 
Traon D., Amat L., Zotz F., Jardin P., 2014. A legal framework for plant biostimulants and agronomic fertilizer additives in the EU, Report for the European Commission Enterprise \& Industry Directorate - General, Arcadia International.

Trawczyński C., 2014. Impact of amino acid biostimulators - Tecamin - on the Yield and Quality of Potato (in Polish). Ziemniak Polski, 3, 29-34.

Urbanowicz J., 2010. Response of potato cultivars to applied pesticides (in Polish). Ziemniak Polski. 2, 31-34.

Zarzecka K., Gugała M. 2012. Yield-forming Impact of Soil Fertilizer UGmax in the cultivation of Potato (in Polish). Inżynieria ekologiczna, 28, 144-148.

Zarzecka K., Gugała M., Dołęga H., 2013. Control of the Degree of Potato Infestation by the Use of Herbicides (in Polish). Biul. IHAR, 267, 113-119.

Zydlik Z., Zydlik P., 2013. The effect of microbiological products on soil properties in the conditions of replant disease. Zemdirbyste-Agriculture, 100(1), 19-24, doi:10.13080/z-a.2013.100.003

Żurawicz E., Masny A., Basak A. 2004. Productivity stimulation in strawberry by application of plant bioregulators. Acta Horticulturae, 653, 155-160, doi:10.17660/ActaHortic.2004.653.21

\section{WPŁYW BIOSTYMULATORÓW WZROSTU I HERBICYDU NA PLON ZIEMNIAKA JADALNEGO}

\section{Alicja Joanna Baranowska}

Zakład Rolnictwa, Katedra Nauk Technicznych, Wydział Nauk Ekonomicznych i Technicznych

Państwowa Szkoła Wyższa im. Papieża Jana Pawła II w Białej Podlaskiej

ul. Sidorska 95/97, 21-500 Biała Podlaska

e-mail: alabar@tlen.pl

Streszczenie. Celem badań było określenie wpływu metod pielęgnacji z zastosowaniem biostymulatorów wzrostu i herbicydu na plon ogólny bulw trzech odmian ziemniaka jadalnego. Badania polowe przeprowadzono w latach 2015-2017 w rejonie Polski wschodniej, w województwie lubelskim. Doświadczenia założono metodą losowanych podbloków w trzech powtórzeniach. Badanymi czynnikami były: I. czynnik - trzy wczesne odmiany ziemniaka jadalnego (Owacja, Bellarosa, Vineta), II. czynnik - metody pielęgnacji z zastosowaniem biostymulatorów wzrostu i herbicydu: GreenOk-Uniwersal Pro i Asahi SL oraz ich kombinacja z herbicydem Avatar 293 ZC. Największy plon ogólny bulw uzyskano na obiekcie 4., na którym do wschodów zastosowano pielęgnację mechaniczną, a po ostatecznym ukształtowaniu redlin tuż przed wschodami herbicyd Avatar $293 \mathrm{ZC}$ w dawce $1,5 \mathrm{dm}^{3} \cdot \mathrm{ha}^{-1}$ i następnie po wschodach trzykrotnie aplikowano bioaktywator GreenOK Universal-PRO w dawkach: $0,10 \mathrm{dm}^{3} \cdot \mathrm{ha}^{-1}$ - pełnia-koniec wschodów $+0,15 \mathrm{dm}^{3} \cdot \mathrm{ha}^{-1}$ - zakrywanie międzyrzędzi $+0,15 \mathrm{dm}^{3} \cdot \mathrm{ha}^{-1}$ - zawiązywanie pąków kwiatowych (średnio $41,8 \mathrm{t} \cdot \mathrm{ha}^{-1}$ ) oraz z obiektu 5., na którym do wschodów stosowano pielęgnację mechaniczną, a po ostatecznym ukształtowaniu redlin przed wschodami roślin ziemniaka aplikowano herbicyd Avatar 293 ZC w dawce $1,5 \mathrm{dm}^{3} \cdot \mathrm{ha}^{-1}$ (średnio $40,6 \mathrm{t} \cdot \mathrm{ha}^{-1}$ ). Na wielkość plonu ogólnego istotny wpływ miały również uprawiane $\mathrm{w}$ doświadczeniu odmiany ziemniaka oraz warunki meteorologiczne podczas prowadzenia badań. Najwyżej plonowała Owacja (średnio 41,4 t·ha-1 ). Największy plon ogólny zebrano w 2016 roku (średnio 42,8 $\mathrm{t} \cdot \mathrm{ha}^{-1}$ ). Stwierdzono również istotny wpływ czynników doświadczenia na strukturę plonu bulw dużych.

Słow a kluczowe: ziemniak, plon ogólny, biostymulatory, herbicyd 